\title{
Sesamin ameliorates oxidative stress and mortality in kainic acid-induced status epilepticus by inhibition of MAPK and COX-2 activation
}

Peiyuan F Hsieh ${ }^{1,2^{*}}$, Chien-Wei Hou ${ }^{3 *}$, Pei-Wun Yao ${ }^{3}$, Szu-Pei Wu ${ }^{3}$, Yu-Fen Peng ${ }^{3}$, Mei-Lin Shen ${ }^{1}$, Ching-Huei Lin ${ }^{1}$, Ya-Yun Chao ${ }^{1}$, Ming-Hong Chang ${ }^{1}$ and Kee-Ching Jeng ${ }^{4,5+}$

\begin{abstract}
Background: Kainic acid (KA)-induced status epilepticus (SE) was involved with release of free radicals. Sesamin is a well-known antioxidant from sesame seeds and it scavenges free radicals in several brain injury models. However the neuroprotective mechanism of sesamin to KA-induced seizure has not been studied.

Methods: Rodents (male FVB mice and Sprague-Dawley rats) were fed with sesamin extract ( $90 \%$ of sesamin and $10 \%$ sesamolin), $15 \mathrm{mg} / \mathrm{kg}$ or $30 \mathrm{mg} / \mathrm{kg}$, for 3 days before KA subcutaneous injection. The effect of sesamin on KAinduced cell injury was also investigated on several cellular pathways including neuronal plasticity (RhoA), neurodegeneration (Caspase-3), and inflammation (COX-2) in PC12 cells and microglial BV-2 cells.

Results: Treatment with sesamin extract (30 mg/kg) significantly increased plasma $\alpha$-tocopherol level $50 \%$ and $55.8 \%$ from rats without and with KA treatment, respectively. It also decreased malondialdehyde (MDA) from 145\% to $117 \%(p=0.017)$ and preserved superoxide dismutase from $55 \%$ of the vehicle control mice to $81 \%$ of sesamintreated mice, respectively to the normal levels $(p=0.013)$. The treatment significantly decreased the mortality from $22 \%$ to $0 \%$ in rats. Sesamin was effective to protect PC12 cells and BV-2 cells from KA-injury in a dose-dependent manner. It decreased the release of $\mathrm{Ca}^{2+}$, reactive oxygen species, and MDA from PC12 cells. Western blot analysis revealed that sesamin significantly reduced ERK1/2, p38 mitogen-activated protein kinases, Caspase-3, and COX-2 expression in both cells and RhoA expression in BV-2 cells. Furthermore, Sesamin was able to reduce $\mathrm{PGE}_{2}$ production from both cells under KA-stimulation.
\end{abstract}

Conclusions: Taken together, it suggests that sesamin could protect KA-induced brain injury through antiinflammatory and partially antioxidative mechanisms.

Keywords: Status epilepticus, PC12 cells, BV-2 cells, sesamin, kainic acid, reactive oxygen species, thiobarbituric acid reactive substances, nitric acid, superoxide dismutase, mitogen-activated protein kinases, COX-2

\section{Background}

Status epilepticus (SE) is defined as a period of continuous seizure activity [1,2]. Prolonged febrile seizures and SE have been implicated as a major predisposing factor for the development of mesial temporal sclerosis and temporal lobe epilepsy $[1,3]$. This emergency condition requires a prompt and appropriate treatment to prevent

\footnotetext{
* Correspondence: pfhsieh@vghtc.gov.tw; rolis.hou@mail.ypu.edu.tw † Contributed equally

'Division of Neurology, Taichung Veterans General Hospital, Taichung, Taiwan

${ }^{3}$ Department of Biotechnology, Yuanpei University, Hsinchu, Taiwan Full list of author information is available at the end of the article
}

brain damage and eventual death. In animal models, similar pathologic changes can be observed with electrically and chemically induced seizures [4-7]. Animal studies show that $\mathrm{SE}$ causes recurrent spontaneous seizures (epilepsy) $[6,8,9]$ and releases free radicals from experimental models of kainic acid (KA), pilocarpine, pentylenetetrazole, and ferric chloride [10-14].

$\mathrm{KA}$, a glutamate related chemical, induces neuronal excitability, reactive oxygen species (ROS) production and lipid peroxidation in neurons [15-17]. It triggers neuronal membrane depolarization by the release of calcium ions which are involved in nerve impulse
C Biomed Central 
transmission as the calcium action potential reaches the synapse [15]. The apoptosis of nerve cells can be triggered by a large number of intracellular calcium influx [18]. Mitogen-activated protein kinases (MAPKs) and Rho kinases are also associated with seizures, inflammation and apoptosis [19-21].

Sesamin and sesamolin are the major lignans from sesame seeds. Previously, we and others report that sesamin can protect against hypoxia-, $\mathrm{H}_{2} \mathrm{O}_{2}$-or 1methyl-4-phenyl-pyridine $\left(\mathrm{MPP}^{+}\right)$-induced brain and PC12 cells injuries [22,23]. Various plant antioxidants have been shown to protect brain form KA-induced calcium ions and ROS [24-26]. Sesamin also inhibits nitric oxide (NO) and cytokine production in lipopolysaccharide (LPS)-and oxidative-stressed BV-2 microglia $[27,28]$.

It is perceivable that sesamin could protect animal from KA-induced SE as in other brain injury models. Therefore, this study investigated the effect of sesamin on the KA-induced SE animals as well as the protective mechanism in neuronal PC12 cells and microglial BV-2 cells.

\section{Methods \\ Reagents}

Pure sesamin and sesamin extract $(90 \%$ sesamin and $10 \%$ sesamolin, as determined by HPLC) were purchased from Joben Bio-medical co. (Kaohsiung, Taiwan). Kainic acid (KA) was obtained from Sigma-Aldrich (Steinheim, Germany) and Cayman Chemical (Ann Arbor, MI, USA), 2', 7'-dichlorodihydrofluorescein diacetate $\left(\mathrm{H}_{2}\right.$ DCF-DA) was obtained from Molecular Probes (Eugene, OR, USA).

\section{Oxidative Stress in mice}

Adult male FVB mice, 23-25 g of weight, were used for the study. SE was induced with $\mathrm{KA}(30 \mathrm{mg} / \mathrm{ml}$ in phosphate-buffered saline (PBS), $30 \mathrm{mg} / \mathrm{kg}$, s.c.). Sesamin extract was diluted with corn oil $(30 \mathrm{mg} / \mathrm{ml})$. The animals were fed with 2 different dosages of sesamin extract $(15 \mathrm{mg} / \mathrm{kg}$ or $30 \mathrm{mg} / \mathrm{kg})$ by gavage for 3 days before the KA experiment. The vehicle control group was fed with equal volume of corn oil. The procedures were approved by the Institutional Animal Care and Use Committee, Taichung Veterans General Hospital (IACUC Approval No. LA-97490) and all possible steps were taken to avoid animals' suffering at each stage of experiments.

Diazepam at lethal dosage, $60 \mathrm{mg} / \mathrm{kg}$ i.p., was given to stop seizures $2 \mathrm{~h}$ after KA injection and the animal was sacrificed by decapitation under $\mathrm{CO}_{2}$ asphyxia. The naïve animal serves as a control. The whole brain was removed and immediately frozen in liquid nitrogen and stored at $-70^{\circ} \mathrm{C}$ until use.
Malondialdehyde (MDA) as a part of thiobarbituric acid reacting substances (TBARS) was used as an indicator of lipid peroxidation. To estimate oxidative stress, the amount of TBARS in the brain from each group was measured. Manual homogenization of brains was carried out at $4^{\circ} \mathrm{C}$ with a cold buffer. Protein concentration of the homogenate was determined by BCA protein assay using bovine serum albumin as a standard. The detection of TBARS was from the modified method of Ohkawa [29]. Briefly, the sample $(0.2 \mathrm{ml})$ was mixed with the same volume of $20 \%(\mathrm{w} / \mathrm{v})$ trichloroacetic acid and $1 \%(\mathrm{w} / \mathrm{v})$ thiobarbituric acid in $0.3 \%(\mathrm{w} / \mathrm{v}) \mathrm{NaOH}$. The mixture was heated in the water bath at $95^{\circ} \mathrm{C}$ for $40 \mathrm{~min}$, cooled to room temperature and centrifugation at $5000 \mathrm{rpm}$ for $5 \mathrm{~min}$ at $4^{\circ} \mathrm{C}$. The fluorescence of the supernatant was determined by a spectrophotometer with excitation at $544 \mathrm{~nm}$ and emission at $590 \mathrm{~nm}$.

Superoxide dismutase (SOD) activity was determined by a RANSOD kit (Randox, USA). This method was based on the formation of red formazan from the reaction of 2-(4-iodophenyl)-3-(4-nitrophenol)-5-phenyltetrazolium chloride and superoxide radical and assayed in a spectrophotometer at $505 \mathrm{~nm}$. The inhibition of the produced chromogen was proportional to the activity of the SOD present in the sample. A 50\% inhibition was defined as one unit of SOD, and specific activity was expressed as units per milligram protein.

\section{Measurement of tocopherols}

Plasma $\alpha$-tocopherol was determined by HPLC method. Briefly, plasma was treated with anti-oxidant reagent (0.25\% BHT and $0.2 \%$ vitamin $\mathrm{C}$ in methanol, $1: 7)$, mixed and centrifuged for $10 \mathrm{~min} \times 12000 \mathrm{~g}$. Sample $(20 \mu \mathrm{l})$ or internal control was then injected to HPLC system (BAS PM-80) with C18 column $(4.6 \times 150 \mathrm{~mm}$, $5 \mu \mathrm{m}$; mobile phase, $95 \%$ methanol, flow rate: $1.0 \mathrm{ml} /$ $\mathrm{min}$ ) and fluorescence detector with $296 \mathrm{~nm}$ excitation, and $340 \mathrm{~nm}$ emission.

\section{Mortality and behavior}

Adult male Sprague-Dawley rats weighing 380-420 g were used to study the protective effect of sesamin extract. Rats were fed with sesamin extract $(30 \mathrm{mg} / \mathrm{kg} /$ day) for 3 days before the SE experiment. The control group was treated with the vehicle corn oil. SE was induced with kainic acid (12 mg/kg, in PBS, s.c.). Each behavioral seizure was recorded according to a modified classification from Racine [30]: 0, immobility or exploring; 1 , facial clonus; 2 , head nodding; 3 , unilateral forelimb clonus; 4, bilateral forelimb clonus and rearing; 5 , falling; 6 , repeated falling; 7, bouncing; 8 , generalized tonus. Four behavioral patterns of SE could be recognized: immobile (class 0 ), exploratory (class 0 ), masticatory (class 1-2) and clonic (class 3-8) [31]. Diazepam, 25 
$\mathrm{mg} / \mathrm{kg}$ i.p., was given to stop seizures at $5 \mathrm{~h}$ of $\mathrm{SE}$ and the $10-\mathrm{h}$ mortality rate was recorded.

\section{Cell culture}

Rat pheochromacytoma (PC12) cells and murine microglial BV-2 cells were maintained in Dulbecco's modified Eagle's medium (DMEM) supplemented with $10 \%$ fetal bovine serum (FBS), 5\% heat-inactivated horse serum, $100 \mathrm{U} / \mathrm{ml}$ penicillin and $100 \mu \mathrm{g} / \mathrm{ml}$ streptomycin at $37^{\circ} \mathrm{C}$ in a humidified incubator under $5 \% \mathrm{CO}_{2}$. Confluent cultures were passaged by trypsinization. For experiments, cells were washed twice with warm DMEM (without phenol red), then treated in serum-free medium. In all experiments, cells were treated with and without sesamin and/or KA-stress for the indicated times.

\section{Cell viability}

Cell viability was measured with blue formazan that was metabolized from colorless 3-(4,5-dimethyl-thiazol-2-yl)2,5-diphenyl tetrazolium bromide (MTT) by mitochondrial dehydrogenases, which are active only in live cells. PC12 cells were pre-incubated in 24-well plates at a density of $5 \times 10^{5}$ cells per well for $24 \mathrm{~h}$, and then washed with PBS. Cells with various concentrations of sesamin were treated with $150 \mathrm{mM} \mathrm{KA}$ for $24 \mathrm{~h}$, and grown in $0.5 \mathrm{mg} / \mathrm{ml} \mathrm{MTT}$ at $37^{\circ} \mathrm{C}$. One hour later, 200 $\mu \mathrm{l}$ of solubilization solution was added to each well and absorption values read at $540 \mathrm{~nm}$ on an automated spectraMAX 340 (Molecular Devices, Sunnyvale, CA, USA) microtiter plate reader. Data were expressed as the mean percent of viable cells vs. control.

\section{Lactate dehydrogenase (LDH) release assay}

Cytotoxicity was determined by measuring the release of LDH. PC12 cells or BV-2 cells with various concentrations of sesamin were treated with $150 \mathrm{mM} \mathrm{KA}$ for 24 $\mathrm{h}$ and the supernatant was used to assay LDH activity. The reaction was initiated by mixing $0.1 \mathrm{ml}$ of cell-free supernatant with potassium phosphate buffer containing nicotinamide adenine dinucleotide (NADH) and sodium pyruvate in a final volume of $0.2 \mathrm{ml}$ to 96 -well plate. The rate of absorbance was read at $490 / 630 \mathrm{~nm}$ on a spectraMAX 340 instrument. Data were expressed as the mean percent of viable cells vs. $150 \mathrm{mM}$ KA control.

\section{Calcium release}

PC12 cells or BV-2 cells with various concentrations of sesamin were treated with $150 \mathrm{mM} \mathrm{KA}$ for $24 \mathrm{~h}$ and the supernatant was used to assay the release of $\mathrm{Ca}^{2+}$. The $10 \mu \mathrm{l}$ supernatant was added to $1 \mathrm{ml} \mathrm{Ca}^{2+}$ reagent (Diagnostic Systems, Holzheim, Germany) and mixed well, stood for $5 \mathrm{~min}$, then transferred the $100 \mu \mathrm{l}$ aliquot to 96 well. The calcium concentration was determined using a microplate reader with a $620 \mathrm{~nm}$ absorbance and quantified with a $10 \mathrm{mg} / \mathrm{ml} \mathrm{Ca}^{2+}$ standard solution.

\section{Reactive oxygen species generation}

Intracellular accumulation of ROS was determined with $\mathrm{H}_{2}$ DCF-DA. This nonfluorescent compound accumulates within cells upon deacetylation. $\mathrm{H}_{2}$ DCF then reacts with ROS to form fluorescent dichlorofluorescein (DCF). PC12 cells or BV-2 cells were plated in 96-well plates and grown for $24 \mathrm{~h}$ before addition of DMEM plus $10 \mu \mathrm{M} \mathrm{H}_{2}$ DCF-DA, incubation for $60 \mathrm{~min}$ at $37^{\circ} \mathrm{C}$, and treatment with $150 \mu \mathrm{M}$ KA for 60 or $120 \mathrm{~min}$. Cells were then washed twice with room temperature Hank's balanced salt solution (HBSS without phenol red). Cellular fluorescence was monitored on a Fluoroskan Ascent fluorometer (Labsystems Oy, Helsinki, Finland) using an excitation wavelength of $485 \mathrm{~nm}$ and emission wavelength of $538 \mathrm{~nm}$.

\section{Measurement of lipid peroxidation}

Lipid peroxidation is quantified by measuring malondialdehyde (MDA) of PC12 cells by lipid peroxidation (LPO) assay kit (Cayman Chemical, Ann Arbor, MI, USA). This kit works on the principle of condensation of one molecule of either MDA or 4-hydroxyalkenals with two molecules of $\mathrm{N}$-methyl-2-phenylindole to yield a stable chromophore. MDA levels were assayed by measuring the amount expressed in $5 \times 10^{5}$ cells and the absorbance at $500 \mathrm{~nm}$ was determined using an ELISA reader (spectraMAX 340).

\section{Preparation of cell extracts}

Test medium was removed from culture dishes and cells were washed twice with ice-cold PBS, scraped off with a rubber policeman, and centrifuged at $200 \times g$ for $10 \mathrm{~min}$ at $4{ }^{\circ} \mathrm{C}$. The cell pellets were resuspended in an appropriate volume $\left(\sim 4 \times 10^{7}\right.$ cells $\left./ \mathrm{ml}\right)$ of lysis buffer containing 20 $\mathrm{mM}$ Tris- $\mathrm{HCl}, \mathrm{pH} 7.5,137 \mathrm{mM} \mathrm{NaCl}, 1 \mathrm{mM}$ phenylmethylsulfonylfluoride, $10 \mu \mathrm{g} / \mathrm{ml}$ aprotinin, $10 \mu \mathrm{g} / \mathrm{ml}$ leupeptin, and $5 \mu \mathrm{g} / \mathrm{ml}$ pepstain $\mathrm{A}$. The suspension was then sonicated. Protein concentration of samples was determined by Bradford assay (Bio-Rad, Hemel, Hempstead, UK) and samples equilibrated to $2 \mathrm{mg} / \mathrm{ml}$ with lysis buffer.

\section{Western blotting}

Protein samples from PC12 cells or BV-2 cells containing $50 \mu \mathrm{g}$ of protein were separated on $12 \%$ sodium dodecyl sulfate-polyacrylamide gels and transferred to immobile polyvinylidene difluoride membranes (Millipore, Bedford, MA). Membranes were incubated for $1 \mathrm{~h}$ with $5 \%$ dry skim milk in TBST buffer $(0.1 \mathrm{M}$ Tris- $\mathrm{HCl}$, $\mathrm{pH} 7.4,0.9 \% \mathrm{NaCl}, 0.1 \%$ Tween-20) to block nonspecific binding, and then incubated with rabbit anti-COX-2, Rho A (1:1000; Cayman chemical; Cell Signaling, USA), 
and anti-phospho-MAPKs. Subsequently, membranes were incubated with secondary antibody streptavidinhorseradish peroxidase conjugated affinity goat anti-rabbit IgG (Jackson, West Grove, PA, USA).

\section{Statistical analysis}

Data were expressed as the mean $\pm \mathrm{SD}$ and mean $\pm \mathrm{SE}$, in vivo and in vitro experiments, respectively. For single variable comparisons, Student's test was used. For multiple variable comparisons, data were analyzed by one-way analysis of variance (ANOVA) followed by Scheffe's test or the least significant differences post-hoc test. Categorical variables were analyzed by use of Fisher's exact test, two-tailed Pearson's chi-square test. Kendall's tau-c was used for testing a trend. $P$ values less than 0.05 were considered significant.

\section{Results}

In vivo effect of sesamin extract on the KA-induced oxidative stress

Treatment with sesamin extract $(30 \mathrm{mg} / \mathrm{kg}$ ) significantly increased $50 \%$ and $55.8 \%$ of plasma $\alpha$-tocopherol levels from rats without and with KA treatment, compared to the baseline level, respectively. In contrast, the plasma $\alpha$ tocopherol level did not change in vehicle control rats. The TBARS level of the vehicle control group was $145 \%$ of the naive control animals. The TBARS level of the sesamin (S-30) group was $117 \%$ of the naïve control and significantly different from that of the vehicle control (V-30) ( $p$ $=0.017)$. The sesamin treatment in SE mice increased the SOD activity from $55 \%$ of the vehicle control mice to $81 \%$ of sesamin-treated mice, respectively to the normal levels. ( $p=0.013)$. However at $15 \mathrm{mg} / \mathrm{kg}$ dosage of sesamin treatment, neither TBARS nor SOD activity was different from the vehicle control $(\mathrm{V}-15)(p>0.05$, Table 1$)$.

\section{Effect on mortality and behavior}

Since the lower dosage of sesamin $(15 \mathrm{mg} / \mathrm{kg})$ did not have a good antioxidant effect, we used the higher dosage for the next experiment. The result showed that treatment with sesamin extract $(30 \mathrm{mg} / \mathrm{kg})$ on the rats with KA-induced SE decreased the mortality rate from $22 \%$ of the vehicle $(\mathrm{V}-30)$ group to $0 \%(p=0.049)$. However, sesamin extract did not significantly attenuate the maximal seizure classes or the predominant behavioral seizure patterns as compared with the vehicle ( $p$ $>0.05$, Tables 2 and 3). Nevertheless, there was a trend of decreasing the clonic pattern of SE by sesamin treatment that $8 / 23(35 \%)$ in the vehicle $(\mathrm{V}-30)$ group dropped to $3 / 22(14 \%)$ in the sesamin (S-30) group (Table 3).

\section{In vitro protection of KA toxicity}

KA can induce free radicals and damage neuronal cells, therefore the cell viability and LDH released from PC12 cells were measured using MTT and LDH ELISA assays [15]. As shown in Figure 1, PC12 cells were exposed to $150 \mu \mathrm{M} \mathrm{KA}$ for $24 \mathrm{~h}$ were protected by the presence of sesamin $(0.1,0.5,1.0$, or $2.0 \mu \mathrm{M})$. KA-induced LDH released was reduced and the cell viability was increased by sesamin treatment. Similarly, BV-2 cells were protected by sesamin under KA stimulation (data not shown).

\section{$\mathrm{KA}$-induced calcium release}

KA triggers neurons membrane depolarization by the release of calcium ions [18]. Our result showed that KA induced calcium release from both $\mathrm{PC} 12$ and BV-2 cells in a time-dependent manner and sesamin reduced the calcium release more prominently from BV-2 cells than from PC12 cells (Figure 2).

\section{KA-induced ROS and lipid peroxidation}

KA-treated PC12 cells or BV-2 cells increased DCF fluorescence nearly one-fold after $120 \mathrm{~min}$ as compared with the control cells. Sesamin protected cells against KA-cytotoxicity by decreasing the ROS accumulation (DCF signals) in both cells (Figure 3). Marked increase

Table 1 Effects of sesamin extract on TBARS (nmol/mg protein) and SOD (units/mg protein) in the mice with 2-h KAinduced SE

\begin{tabular}{|c|c|c|c|c|c|c|c|}
\hline \multirow[t]{2}{*}{ Variable } & \multirow{2}{*}{$\frac{\text { Vehicle }}{M \pm S D}$} & \multirow{2}{*}{$\begin{array}{l}\text { Sesamin extract } \\
\mathrm{M} \pm \mathrm{SD}\end{array}$} & \multirow{2}{*}{$\begin{array}{l}\text { Naive } \\
M \pm S D\end{array}$} & \multirow[t]{2}{*}{$P$-value ${ }^{a}$} & \multicolumn{3}{|c|}{$P$-value ${ }^{b}$} \\
\hline & & & & & $(\mathrm{V}, \mathrm{S})$ & $(\mathrm{V}, \mathrm{N})$ & $(\mathrm{S}, \mathrm{N})$ \\
\hline \multicolumn{8}{|l|}{15 mg/kg } \\
\hline TBARS & $0.96 \pm 0.22$ & $0.85 \pm 0.10$ & $0.57 \pm 0.04$ & $0.001^{* *}$ & 0.225 & $0.0002^{* *}$ & $0.004^{* *}$ \\
\hline SOD & $4.18 \pm 1.01$ & $5.27 \pm 2.01$ & $8.79 \pm 1.22$ & $0.005^{* *}$ & 0.686 & $0.003^{* *}$ & $0.006^{* *}$ \\
\hline \multicolumn{8}{|l|}{30 mg/kg } \\
\hline TBARS & $0.86 \pm 0.14$ & $0.69 \pm 0.14$ & $0.59 \pm 0.06$ & $0.003^{* *}$ & $0.017^{*}$ & $0.001^{* *}$ & 0.126 \\
\hline SOD & $5.17 \pm 1.90$ & $7.54 \pm 2.10$ & $9.48 \pm 1.17$ & $0.0004^{* *}$ & $0.013^{*}$ & $0.0001^{* *}$ & $0.049^{*}$ \\
\hline
\end{tabular}

$\mathrm{M} \pm \mathrm{SD}$ : mean \pm standard deviation. $\mathrm{N}$ : naïve. S: sesamin extract. V: vehicle.

a One-way ANOVA test.

${ }^{\mathrm{b}}$ Least significant differences post-hoc test. ${ }^{*} P<0.05,{ }^{* *} P<0.01$. 
Table 2 Effects of sesamin extract on the maximal seizure class (MSC) and mortality rate of the rats with 5-h KAinduced SE

\begin{tabular}{llll}
\hline Variables & $\begin{array}{l}\text { Control } \\
(\mathbf{V}-30) \\
\mathrm{n}(\%)\end{array}$ & $\begin{array}{l}\text { Sesamin } \\
(\mathrm{S}-30) \\
\mathrm{n}(\%)\end{array}$ & P-value \\
\hline Mortality & $5(22)$ & $0(0)$ & $0.049^{\mathrm{a}}$ \\
MSC & & & \\
$\mathbf{1 - 2}$ & $2(9)$ & $1(4)$ & $0.797^{\mathrm{b}}$ \\
$\mathbf{3 - 6}$ & $17(74)$ & $16(73)$ & $0.530^{\mathrm{c}}$ \\
$\mathbf{7 - 8}$ & $4(17)$ & $5(23)$ & \\
\hline
\end{tabular}

${ }^{a}$ Fisher's exact test.

b Pearson's chi-square test: all seizure classes were taken together.

' Kendall's tau-c: all seizure classes were taken together.

S-30: sesamin extract $(30 \mathrm{mg} / \mathrm{kg})$. V-30: vehicle.

in MDA level was observed in KA-exposed cells as compared with the control cells (Figures 4-5). Treatment with sesamin significantly reduced MDA levels as compared to the KA-treated control $(p<0.01$,$) .$

\section{Caspase-3 activation}

Apoptotic signaling pathways were investigated in KAtreated PC12 cells and BV-2 cells. The results showed that KA increased Caspase- 3 activation but sesamin reduced the Caspase-3 expression dose-dependently in both cells (Figure 6 and data not shown).

\section{COX-2 and MAPK activation}

Seizures, inflammation and apoptosis in neuronal cells are known to be initiated with several signaling pathways such as MAPKs and Rho kinases [19-21]. Therefore, the KA induced the activation of signaling pathways were studied in PC12 cells and BV-2 cells for MAP kinases (JNK, ERK, p38), RhoA, and COX-2 (Figure 6). We evaluated the effect of sesamin on KAinduced pathways in PC12 cells at 10,30, and $60 \mathrm{~min}$ and in BV-2 cells $30,60,120$ min by Western blot. Western blot analysis revealed that sesamin $(50 \mu \mathrm{M})$ significantly reduced ERK1/2, p38 MAPKs and COX-2 expression in both cells and RhoA expression in BV-2 cells as compared to KA controls.

Table 3 The effect of sesamin extract on the predominant behavior patterns of the rats with 5-h KAinduced SE

\begin{tabular}{llll}
\hline Behavior Pattern & $\begin{array}{l}\text { Control } \\
(\mathbf{V}-30) \\
\mathbf{n}(\%)\end{array}$ & $\begin{array}{l}\text { Sesamin (S-30) } \\
\mathbf{n}(\%)\end{array}$ & P-value \\
\hline Immobile or Exploratory & $11(48)$ & $12(54)$ & $0.211^{\mathrm{a}}$ \\
Masticatory & $4(17)$ & $7(32)$ & $0.323^{\mathrm{b}}$ \\
Clonic & $8(35)$ & $3(14)$ &
\end{tabular}

a Pearson's chi-square test: all behavioral patterns were taken together.

${ }^{b}$ Kendall's tau-c: all behavioral patterns were taken together.

S-30: sesamin extract $(30 \mathrm{mg} / \mathrm{kg})$. V-30: vehicle.

\section{$\mathrm{PGE}_{2}$ production}

We further evaluated whether the KA-induced COX-2 change would affect $\mathrm{PGE}_{2}$ production. The result showed that sesamin reduced the $\mathrm{PGE}_{2}$ production in both KA-induced PC12 cells and BV-2 cells as predicted (Figure 7).

\section{Discussion}

The present result showed that sesamin protected animals from KA-induced brain injury. MDA and mortality were significantly reduced as compared with the nontreated one. The decreased mortality in the sesamintreated animals could also be confirmed by the sesamin effect in vitro that showed a decreased LDH release and Caspase- 3 activation and increased cell viability in KAstimulated PC12 cells.

The neuroprotective effect of sesamin on KA-induced injury was mainly due to its antioxidant effect on reducing of MDA, the product of lipid peroxidation both in vivo and in vitro. The antioxidant effect on reducing of MDA could be attributed to the increased plasma $\alpha$ tocopherol level from the supplementation with sesamin extract (Table 1). This is consistent with a study that reports consumption of sesame seed powder over five weeks increases plasma $\alpha$-tocopherol levels in healthy human volunteers [32]. KA administration is associated with a depletion of ATP levels and accumulation of $\left[\mathrm{Ca}^{2}\right.$ $\left.{ }^{+}\right]_{\mathrm{i}}$. PC12 cells treated with KA for $24 \mathrm{~h}$ reduced cell viability dose-dependently by MTT assay. This was not caused by changes in $\mathrm{pH}$ or osmotic pressure because the inert mannitol at the concentration of $150 \mathrm{mM}$, did not affect cell viability (data not shown). The increase in $\left[\mathrm{Ca}^{2+}\right]_{\mathrm{i}}$ may trigger $\mathrm{Ca}^{2+}$-activated free radicals formation [33]. Sesamin decreased ROS and calcium release from KA-treated PC12 cells and BV-2 cells. This agrees with the earlier reports that antioxidants can protect brain from KA-induced calcium ions and ROS release [24-26]. It is also consistent with the sesamin antioxidant effect that protects hypoxia-or $\mathrm{H}_{2} \mathrm{O}_{2}$-induced PC12 cell injury [22]. A study with defatted sesame seeds extract $(30,100$ and $300 \mathrm{mg} / \mathrm{kg}$ ) given twice orally at $0 \mathrm{~h}$ and $2 \mathrm{~h}$ after onset of ischemia shows the reduction of brain infarct volume dose-dependently and improves sensory-motor function [34]. Thus, suppression of KA-induced ROS and $\mathrm{Ca}^{2+}$ release by sesamin was consistent with these notions. Since seizure can be triggered by the KA-induced calcium ions release, the decreased severity of seizure behavior could be partially attributed to the sesamin antioxidative effect, although it was not statistically significant due to the small sample sizes

Since microglial activation as one mechanism by which early-life seizures contribute to increased vulnerability to neurologic insults in adulthood, therapies that 
(A)

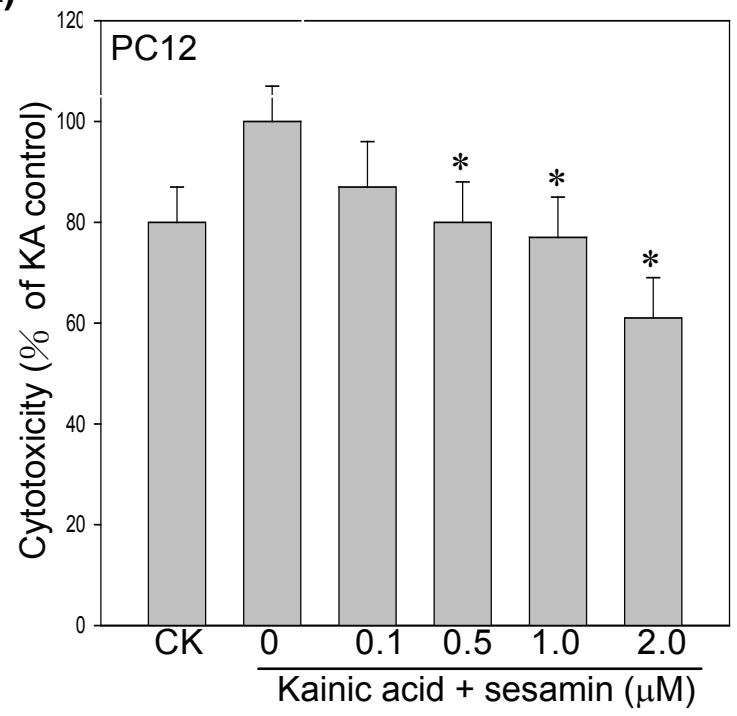

(B)

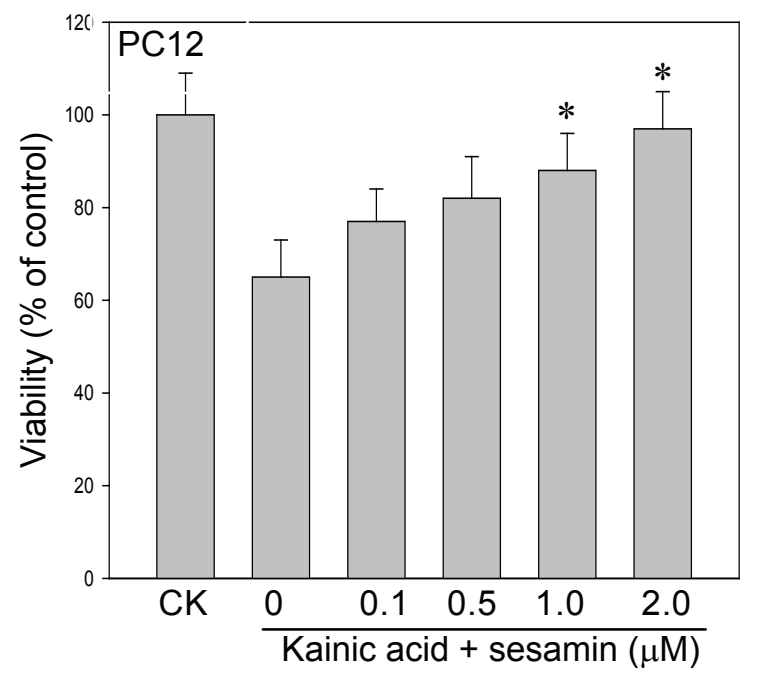

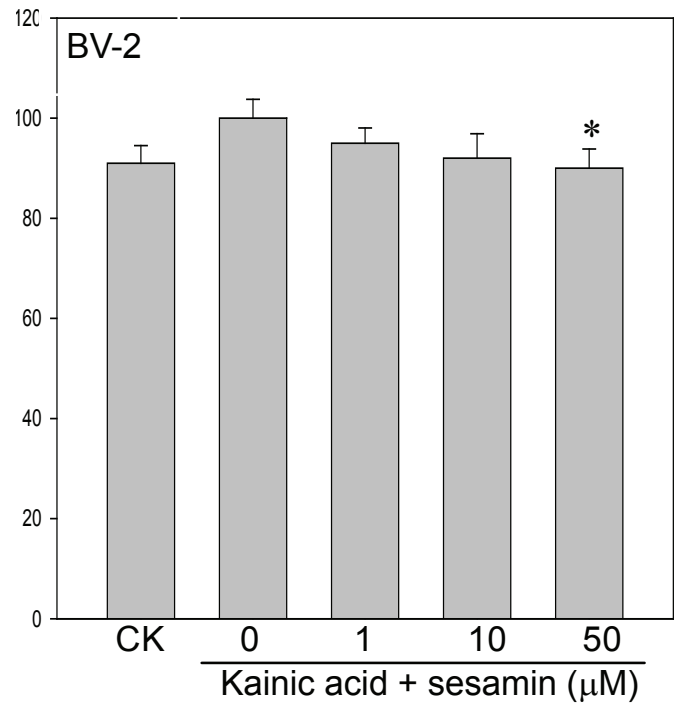

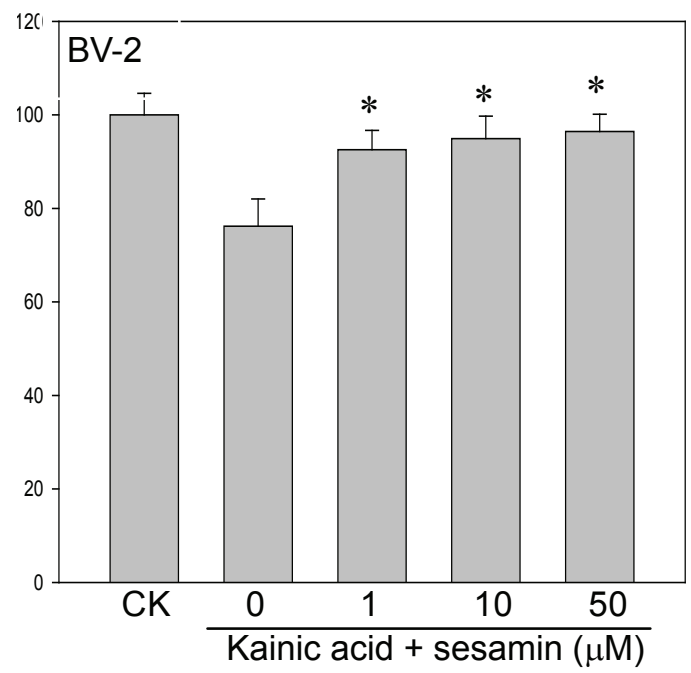

Figure 1 Effect of sesamin on cell viability and cytotoxicity of kainic acid-stressed PC12 cells. Cells were treated with KA (150 $\mu \mathrm{M})$ alone or with various concentrations $(0.1,0.5,1.0,2.0 \mu \mathrm{M})$ of sesamin for $24 \mathrm{~h}$. (A) $\mathrm{LDH}$ release was decreased and (B) cell viability increased by sesamin. ${ }^{*} P<0.01$ as compared to KA control.

regulate of proinflammatory cytokines would be beneficial [35]. Present results showed that NO production in KA-stimulated BV-2 cells was dose-dependently reduced by sesamin and $\mathrm{PGE}_{2}$ production from both cells under KA stress was also significantly reduced. This agrees with other studies that sesamin protects $\mathrm{PC} 12$ cells from $\mathrm{MPP}^{+}$-induced cellular death by increasing the SOD activity and inducible nitric oxide synthase protein (iNOS) expression and microglia from reducing interleukin-6 (IL-6) mRNA levels [23]. We have reported previously that sesamin or sesamolin inhibits NO, iNOS, tumor necrosis factor- $\alpha$ and IL-6 production in LPS-stimulated BV-2 microglia [27]. In addition, sesamin and sesamolin also reduced LPS-activated cytokine, p38 MAPK and NF- $\kappa$ B activations [28].

The role of COX-2 mRNA and protein in KAinduced brain injury has been reported [36-38]. The KA-induced COX-2 expression parallels the appearance of neuronal apoptotic features [36] and involves with free radicals formation [39]. Several protease families are implicated in apoptosis, the most prominent being caspases [40]. We found that KA could 


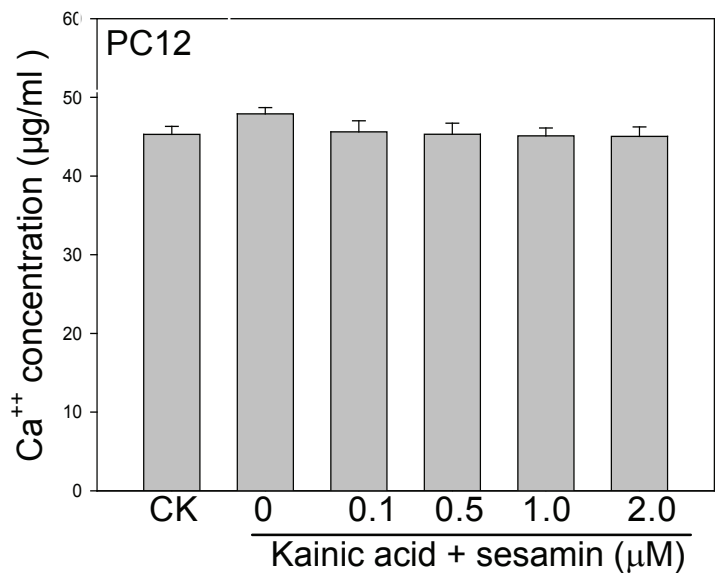

(B)

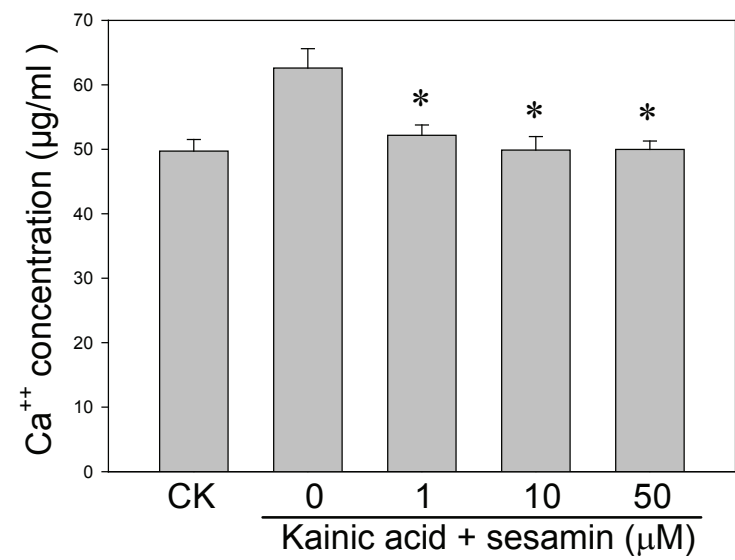

Figure 2 Effect of sesamin on $\mathrm{Ca}^{2+}$ generation from KA-treated PC12 cells and BV-2 cells. Cells were treated with KA (150 $\mu \mathrm{M})$ alone or with various sesamin concentrations (0.1-2.0 $\mu \mathrm{M})$ of sesamin for $24 \mathrm{~h}$. Treatment with sesamin effectively reduced the release of $\mathrm{Ca}^{2+}$ under KA stress. ${ }^{*} P<0.01$ as compared to the KA control.

affect the Caspase- 3 activation in PC12 cells and BV-2 cells and sesamin could reduce both Caspase- 3 expression. Since KA could induce the activation of MAP kinases (JNK, ERK, p38), RhoA and COX-2 in PC12 cells, we found that sesamin suppressed KA-induced COX-2, ERK, and p38 MAPK in PC12 cells and BV-2 cells. Our result is similar to a study of tea extract (TF3) treatment that shows TF3 reduces the gene and protein expression of COX- 2 and iNOS, and NF- $\kappa \mathrm{B}$ activation from cerebral ischemia-reperfusion [41].
(A)

(B)
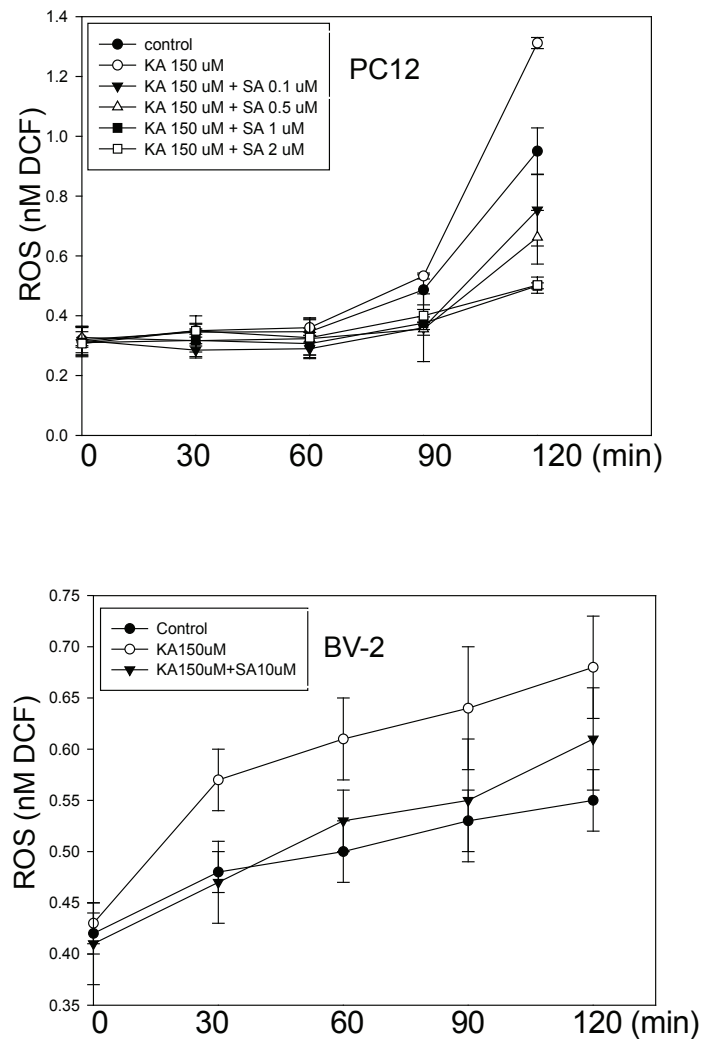

Figure 3 Effect of sesamin on ROS accumulation in PC12 cells and BV-2 cells under KA stress. Sesamin effectively reduced the ROS production from (PC12 cells induced by KA stress $(150 \mu \mathrm{M})$ at 120-min. ${ }^{*} P<0.01$ as compared to the KA control.

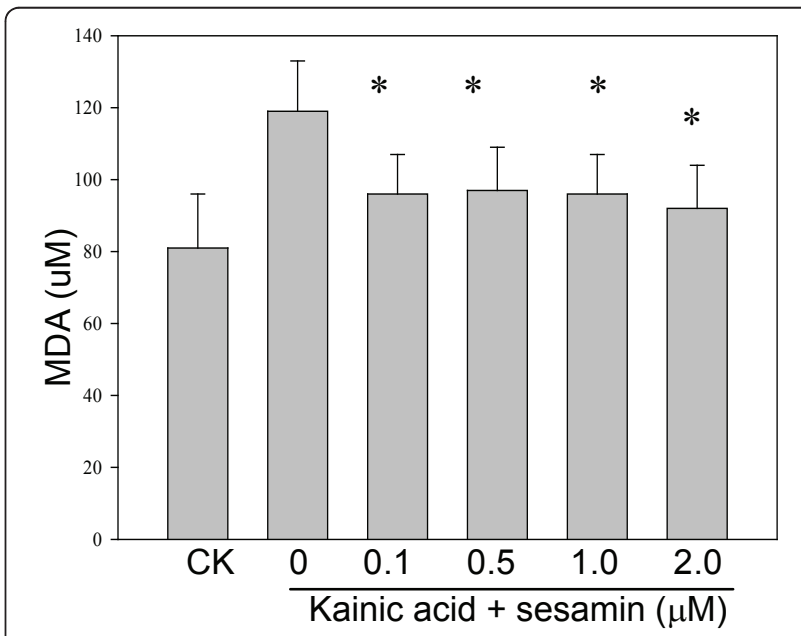

Figure 4 Effect of sesamin on lipid peroxidation of PC12 cells under KA stress. Lipid peroxidation (LPO) was determined by a LPO assay kit (Cayman Chemical, Ann Arbor, MI, USA). Malondialdehyde (MDA) of PC12 cells was induced by 24-h KA stress $(150 \mu \mathrm{M})$ and effectively reduced by sesamin. ${ }^{*} P<0.01$ as compared to the KA control. 


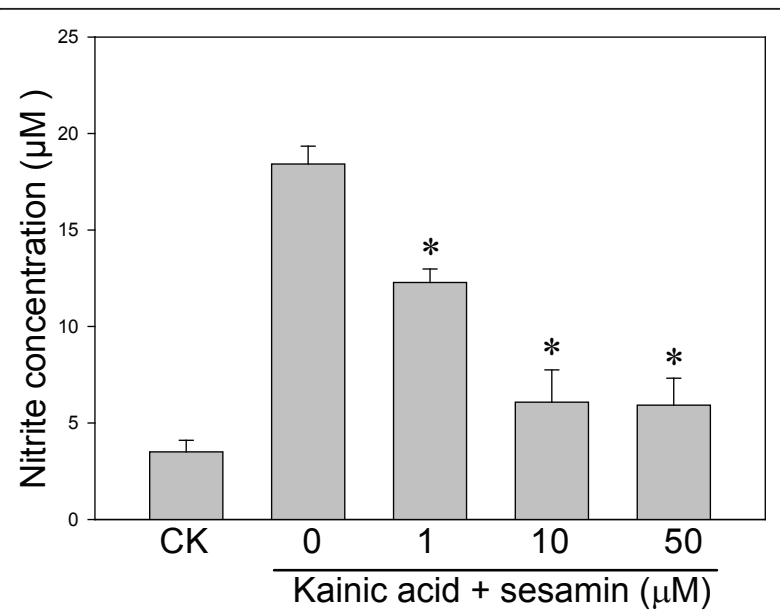

Figure 5 Kainic acid-induced nitrite production. BV-2 cells were treated with KA $(150 \mu \mathrm{M})$ alone or with various sesamin concentrations (1-50 $\mu \mathrm{M})$ for $24 \mathrm{~h}$. KA-induced nitrite production was dose-dependently decreased the treatment with sesamin.

However, KA-induced RhoA pathway in BV-2 cells but not PC12 cells was reduced by sesamin.

Our data also showed that sesamin extract had the tendency to decrease the severity of seizure behavior. A recent study indicated the lack of effectiveness of antioxidants in the kainic acid SE model [42]. However, antioxidants had significant anticonvulsant activity against pilocarpine. This discrepancy could be explained by the fact that KA is a glutamate receptor agonist while pilocarpine is a muscarinic agonist [43]. Because of the small number of animals in our study, the ameliorating effect of sesamin extract on behavioral severity was not statistically significant. Further studies are needed to confirm whether sesamin has direct effects on the seizure behavior and the related molecular mechanism in this issue. The present results are consistent with previous reports that antioxidants such as resveratrol, vitamin-E, melatonin, and lipoic acids are also protective against various animal models of SE in terms of the oxidative stress or convulsions [44-51]. Particularly, resveratrol protects against KA-induced neuronal damage $[7,10,14,49]$. However, in the present study the concentrations of sesamin likely to be achieved in vivo were too low to act as chainbreaking antioxidants. Only higher dose $(30 \mathrm{mg} / \mathrm{kg})$ of sesamin supplementation significantly increased plasma $\alpha$-tocopherol level and reduced the TBARS level as compared with the vehicle control rats. It is more likely that sesamin acts as a pharmacological antioxidant by blocking enzymes or pathways of neuroinflammation that would produce ROS/RNS.

Stopping the seizure activity earlier is the best way to prevent SE-induced free radicals and neuronal damage. However, clinical experience shows that SE can be
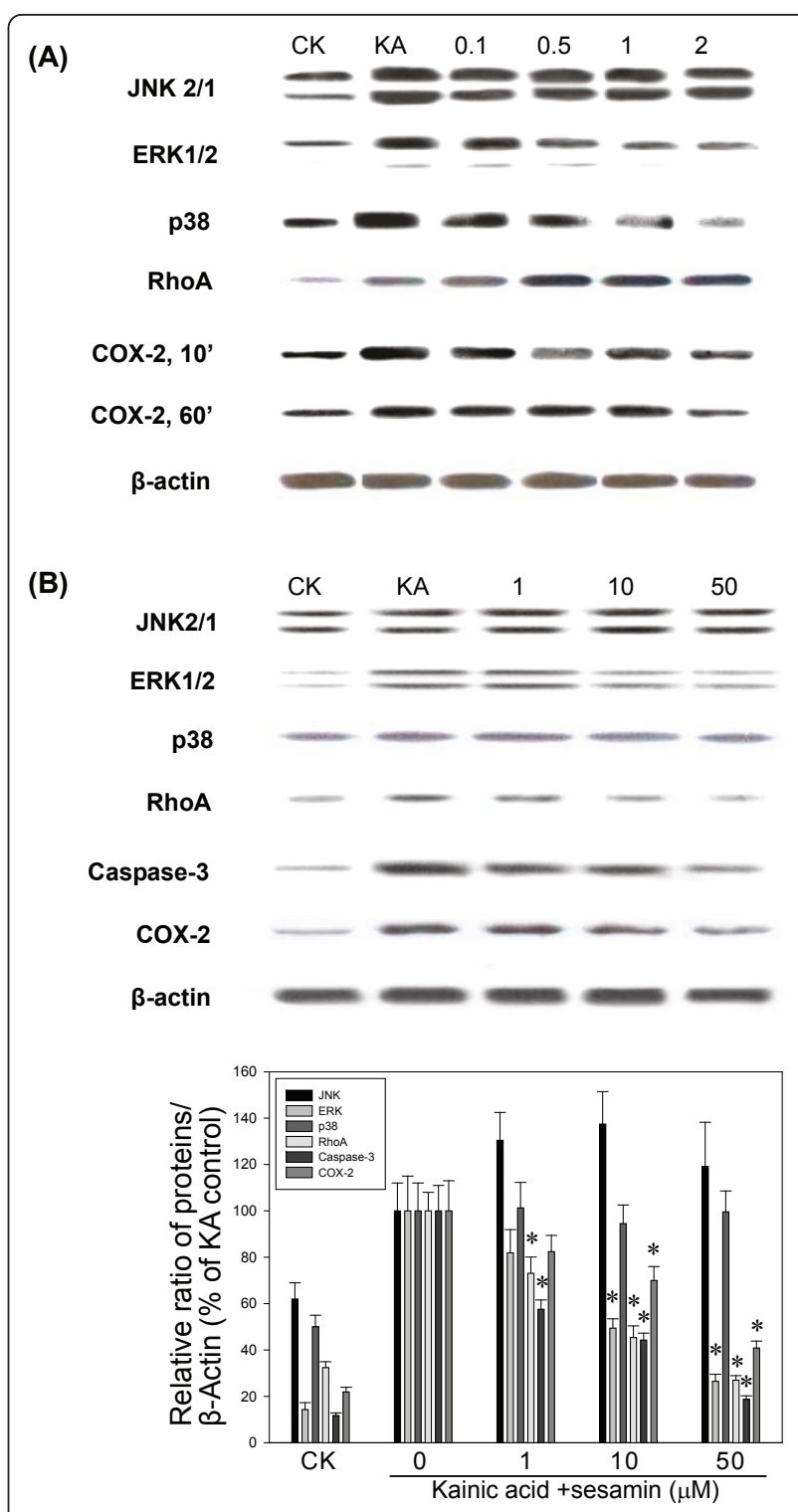

Figure 6 Effect of sesamin on MAP kinases, RhoA and COX-2 activation in PC12 cells and BV-2 cells under KA stress. The effect of sesamin (1-50 $\mu \mathrm{M}$ ) on KA-activated cell signaling pathways was determined by Western blotting under KA stress, (A) PC12 cells for 10-min and 60-min and (B) BV-2 cells for 120 min. Sesamin effectively reduced the activation of COX-2, ERK, p38 MAP kinases. " $P<0.01$ as compared to the KA control. CK: normal control.

refractory to the commonly used medications. Therefore, intervention by antioxidants can be a potential beneficial approach in the treatment of SE.

\section{Conclusion}

Sesamin ameliorates oxidative stress in KA-induced status epilepticus and warrants further study for the molecular mechanism. 
(A)

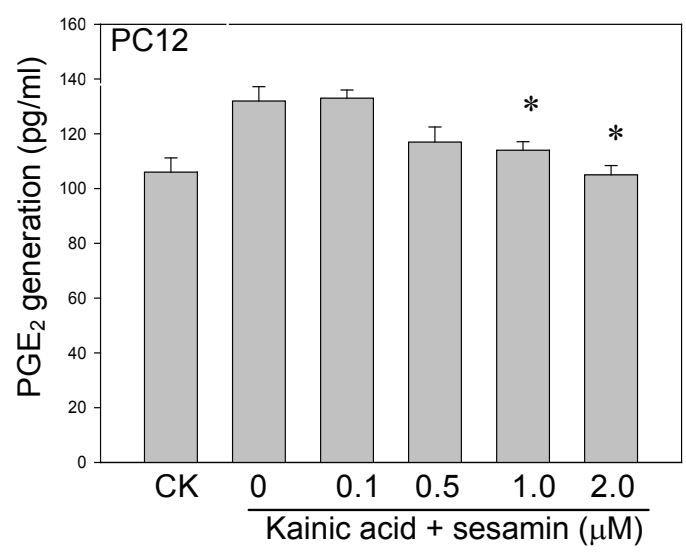

(B)

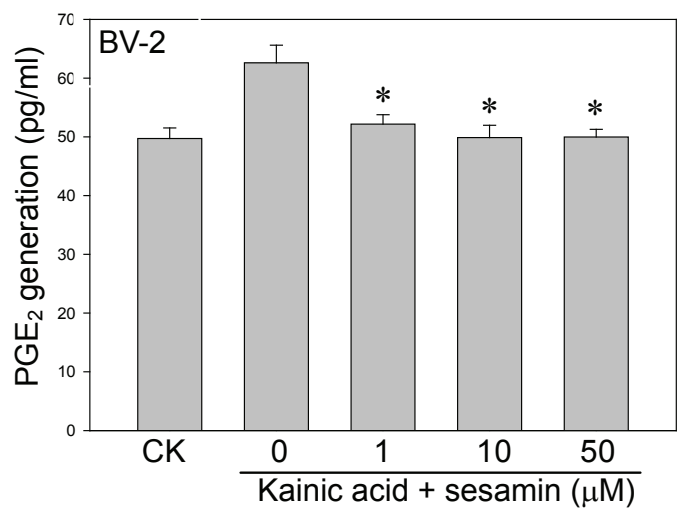

Figure 7 Effect of sesamin on $\mathrm{PGE}_{2}$ production in $\mathrm{PC} 12$ cells and BV-2 cells. Sesamin dose-dependently reduced KA-induced $\mathrm{PGE}_{2}$ production in (A) PC12 cells and (B) BV-2 cells. PGE 2 concentration was determined by ELISA (R\&D) assay. ${ }^{*} P<0.01$ as compared to the KA control.

\section{List of abbreviations}

(COX-2) Cyclooxygenase-2, (DCF) dichlorofluorescein, (DMEM) Dulbecco's modified Eagle's medium, (FBS) fetal bovine serum, ( $\mathrm{H}_{2}$ DCF-DA) 2, $7^{\prime}$ dichlorodihydrofluorescein diacetate, (HBSS) Hank's balanced salt solution, (IL-6) interleukin-6, (iNOS) Inducible-nitric oxide synthase, (KA) Kainic acid, (LDH) Lactate dehydrogenase, (LPO) lipid peroxidation, (LPS) Lipopolysaccharide, (MDA) Malondialdehyde, (MAPKs) Mitogen-activated protein kinases, $\left(\mathrm{MPP}^{+}\right)$1-methyl-4-phenyl-pyridine, (MTT) 3-(4,5-dimethylthiazol-2-yl)-2,5-diphenyl tetrazolium bromide, (NADH) nicotinamide adenine dinucleotide, (NF-kB) Nuclear factor-KB, (NO) Nitric oxide, (PBS) Phosphatebuffered saline, (PC12 cells) Pheochromacytoma, $\left(\mathrm{PGE}_{2}\right)$ Prostaglandin $\mathrm{E}_{2,}$ (ROS) Reactive oxygen species, (SE) Status epilepticus, (SOD) Superoxide dismutase, (TBARS) thiobarbituric acid reacting substances.

\section{Acknowledgements}

This work was supported by grants from the National Science Council, ROC (NSC 93-2314-B-075A-021, NSC 94-2314-B-075A-006) and Taichung Veterans General Hospital (TCVGH-943401A, TCVGH-983401A).

\section{Author details}

'Division of Neurology, Taichung Veterans General Hospital, Taichung, Taiwan. ${ }^{2}$ Graduate Institute of Biomedicine and Biomedical Technology, National Chi Nan University, Nantou, Taiwan. ${ }^{3}$ Department of Biotechnology,
Yuanpei University, Hsinchu, Taiwan. ${ }^{4}$ Department of Physical Education Office, Yuanpei University, Hsinchu, Taiwan. ${ }^{5}$ Department of Medical Research, Taichung Veterans General Hospital, Taichung, Taiwan.

\section{Authors' contributions}

$\mathrm{PFH}$ and CWH participated in the design and Ms editing, in all treatment procedures, data elaboration and seizure and behavior studies. MS, CL, YC participated in all treatment procedures and daily control for animal food intake, weights and SOD and TBARS assay. SPW, YFP participated in all celltreatment procedures, participated in ROS procedures and PWY, western blot and $\mathrm{PGE}_{2}$ assay. $\mathrm{KJ}$ conceived the study and design, analyzed the data and prepared the manuscript. All authors read, discussed and approved the final manuscript.

\section{Competing interests}

The authors declare that they have no competing interests.

Received: 14 December 2010 Accepted: 24 May 2011

Published: 24 May 2011

\section{References}

1. Wasterlain CG, Fujikawa DG, Penix L, Sankar R: Pathophysiological mechanisms of brain damage from status epilepticus. Epilepsia 1993, 34 S37-S53.

2. Millikan D, Rice B, Silbergleit R: Emergency treatment of status epilepticus: current thinking. Emerg Med Clin North Am 2009, 27:101-113.

3. Rocca WA, Sharbrough FW, Hauser WA, Annegers JF, Schoenberg BS: Risk factors for complex partial seizures: a population-based case-control study. Ann Neurol 1987, 21:22-31.

4. Lee B, Cao R, Choi YS, Cho HY, Rhee AD, Hah CK, Hoyt KR, Obrietan K: The CREB/CRE transcriptional pathway: protection against oxidative stress-mediated neuronal cell death. J Neurochem 2009, 108:1251-1265.

5. Penner MR, Pinaud R, Robertson HA: Rapid kindling of the hippocampus protects against neural damage resulting from status epilepticus. Neuroreport 2001, 12:453-457.

6. Turski L, Ikonomidou C, Turski WA, Bortolotto ZA, Cavalheiro EA: Review: cholinergic mechanisms and epileptogenesis. The seizures induced by pilocarpine: a novel experimental model of intractable epilepsy. Synapse 1989, 3:154-171.

7. Wang $Q$, Yu S, Simonyi A, Rottinghaus $G$, Sun GY, Sun AY: Resveratrol protects against neurotoxicity induced by kainic acid. Neurochem Res 2004, 29:2105-2112.

8. Muller-Schwarze AB, Tandon P, Liu Z, Yang Y, Holmes GL, Stafstrom CE: Ketogenic diet reduces spontaneous seizures and mossy fiber sprouting in the kainic acid model. Neuroreport 1999, 10:1517-1522.

9. Wasterlain CG, Shirasaka Y, Mazarati AM, Spigelman I: Chronic epilepsy with damage restricted to the hippocampus: possible mechanisms. Epilepsy Res 1996, 26:255-265.

10. Gupta YK, Briyal S, Chaudhary G: Protective effect of trans-resveratrol gainst kainic acid-induced seizures and oxidative stress in rats. Pharmacol Biochem Behav 2002, 71:245-249.

11. Miyamoto R, Shimakawa S, Suzuki S, Ogihara T, Tamai H: Edaravone prevents kainic acid-induced neuronal death. Brain Res 2008, 1209:85-91.

12. Freitas RM, Sousa FC, Vasconcelos SM, Viana GS, Fonteles MM: Pilocarpineinduced status epilepticus in rats: lipid peroxidation level, nitrite formation, GABAergic and glutamatergic receptor alterations in the hippocampus, striatum and frontal cortex. Pharmacol Biochem Behav 2004, 78:327-332.

13. Bashkatova V, Narkevich V, Vitskova G, Vanin A: The influence of anticonvulsant and antioxidant drugs on nitric oxide level and lipid peroxidation in the rat brain during penthylenetetrazole-induced epileptiform model seizures. Prog Neuropsychopharmacol Biol Psychiatry 2003, 27:487-492.

14. Meyerhoff JL, Lee JK, Rittase BW, Tsang AY, Yourick DL: Lipoic acid pretreatment attenuates ferric chloride-induced seizures in the rat. Brain Res 2004, 1016:139-144.

15. Sun AY, Cheng Y, Bu Q, Oldfield F: The biochemical mechanism of the excitotoxicity of kainic acid. Mol Chem Neuropathol 1992, 17:51-63.

16. Bruce AJ, Baudry M: Oxygen free radicals in rat limbic structures after kainate-induced seizures. Free Radical Biol Med 1995, 18:993-1002. 
17. D'Antuono M, Benini R, Biagini G, D'Arcangelo G, Barbarosie M, Tancredi V Avoli M: Limbic network interactions leading to hyperexcitability in a model of temporal lobe epilepsy. J Neurophysiol 2002, 87:634-639.

18. Arispe N, Pollard HB, Rojas E: $\beta$-Amyloid $\mathrm{Ca}^{2+}$-channel hypothesis for neuronal death in Alzheimer disease. Mol Cell Biochem 1994, 140:119-125.

19. Goodenough S, Davidson M, Chen M, Beckmann A, Pujic Z, Otsuki M, Matsumoto I: Immediate early gene expression and delayed cell death in limbic areas of the rat brain after kainic acid treatment and recovery in the cold. Exp Neurol 1997, 145:451-461.

20. Dubreuil Cl, Marklund N, Deschamps K, Mclntosh TK, McKerracher L: Activation of Rho after traumatic brain injury and seizure in rats. Exp Neurol 2006, 198:361-369.

21. Matagne V, Lebrethon MC, Gérard A, Bourguignon JP: Kainate/estrogen receptor involvement in rapid estradiol effects in vitro and intracellular signaling pathways. Endocrinology 2005, 146:2313-2323.

22. Hou RC, Chen HL, Tzen JT, Jeng KC: Effect of sesame antioxidants on LPSinduced NO production by BV2 microglial cells. Neuroreport 2003, 14:1815-1819.

23. Lahaie-Collins V, Bournival J, Plouffe M, Carange J, Martinoli MG: Sesamin modulates tyrosine hydroxylase, superoxide dismutase, catalase, inducible NO synthase and interleukin- 6 expression in dopaminergic cells under MPP-induced oxidative stress. Oxid Med Cell Longev 2008, 1:54-62.

24. Ma CJ, Kim SR, Kim J, Kim YC: Meso-dihydroguaiaretic acid and licarin A of Machilus thunbergii protect against glutamate-induced toxicity in primary cultures of a rat cortical cells. Br J Pharmacol 2005, 146:752-759.

25. Kanada A, Nishimura Y, Yamaguchi JY, Kobayashi M, Mishima K, Horimoto K, Kanemaru K, Oyama Y: Extract of Ginkgo biloba leaves attenuates kainate-induced increase in intracellular $\mathrm{Ca}^{2+}$ concentration of rat cerebellar granule neurons. Biol Pharm Bull 2005, 28:934-936.

26. Fukumoto LR, Mazza G: Assessing antioxidant and prooxidant activities and phenolic compounds. J Agric Food Chem 2000, 48:3597-3604.

27. Hou RC, Huang HM, Tzen JT, Jeng KC: Protective effects of sesamin and sesamolin on hypoxic neuronal and PC12 cells. J Neurosci Res 2003, 74:123-133.

28. Jeng KC, Hou RC, Wang JC, Ping LI: Sesamin inhibits lipopolysaccharideinduced cytokine production by suppression of p38 mitogen-activated protein kinase and nuclear factor-kappaB. Immunol Lett 2005, 97:101-106.

29. Ohkawa $H$, Ohishi $N$, Yagi $K$ : Assay for lipid peroxides in animal tissues by thiobarbituric acid reaction. Anal Biochem 1979, 95:351-358.

30. Racine RJ: Modification of seizure activity by electrical stimulation. II. Motor seizure. Electroencephalogr Clin Neurophysiol 1972, 32:281-294.

31. Handforth A, Ackermann RF: Functional ${ }^{14} \mathrm{C}$ 2-deoxyglucose mapping of progressive states of status epilepticus induced by amygdala stimulation in rat. Brain Res 1988, 460:94-102.

32. Wu WH, Kang YP, Wang NH, Jou HJ, Wang TA: Sesame ingestion affects sex hormones, antioxidant status, and blood lipids in postmenopausal women. J Nutr 2006, 136:1270-1275.

33. Dykens JA, Stern A, Trenkner E: Mechanisms of kainate toxicity to cerebellar neurons in vitro is analogous to reperfusion tissue injury. $J$ Neurochem 1987, 49:1222-1228.

34. Jamarkattel-Pandit N, Pandit NR, Kim MY, Park SH, Kim KS, Choi H, Kim H, $\mathrm{Bu} Y$ : Neuroprotective effect of defatted sesame seeds extract against in vitro and in vivo ischemic neuronal damage. Planta Med 2010, 76:20-26.

35. Somera-Molina KC, Nair S, Van Eldik LJ, Watterson DM, Wainwright MS: Enhanced microglial activation and proinflammatory cytokine upregulation are linked to increased susceptibility to seizures and neurologic injury in a 'two-hit' seizure model. Brain Res 2009, 1282:162-172.

36. Hashimoto $K$, Watanabe $K$, Nishimura T, lyo M, Shirayama $Y$, Minabe $Y$ : Behavioral changes and expression of heat shock protein HSP-70 mRNA, brain-derived neurotrophic factor mRNA, and cyclooxygenase-2 mRNA in rat brain following seizures induced by systemic administration of kainic acid. Brain Res 1998, 804:212-223.

37. Sandhya TL, Ong WY, Horrocks LA, Farooqui AA: A light and electron microscopic study of cytoplasmic phospholipase $A 2$ and cyclooxygenase-2 in the hippocampus after kainite lesions. Brain Res 1998, 788:223-231.

38. Sanz O, Estrada A, Ferrer I, Planas AM: Differential cellular distribution and dynamics of HSP70, cyclooxygenase-2, and c-Fos in the rat brain after transient focal ischemia or kainic acid. Neurosci 1997, 80:221-232.
39. Candelario-Jalil E, Ajamieh HH, Sam S, Martinez G, Leon OS: Nimesulide limits kainate-induced oxidative damage in the rat hippocampus. Eur J Pharmacol 2000, 390:295-298.

40. Sarker KP, Nakata M, Kitajima I, Nakajima T, Maruyama I: Inhibition of caspase-3 activation by SB 203580, p38 mitogen-activated protein kinase inhibitor in nitric oxide-induced apoptosis of PC-12 cells. J Mol Neurosci 15:243-250.

41. Cai C, Li J, Wu Q, Min C, Ouyang M, Zheng S, Ma W, Lin F: Modulation of the oxidative stress and nuclear factor kappaB activation by theaflavin $3,3^{\prime}$-gallate in the rats exposed to cerebral ischemia-reperfusion. Folia Biol 2007, 53:164-172.

42. $\mathrm{Xu} \mathrm{K}$, Janet $\mathrm{L}$, Stringer $\mathrm{L}$ : Antioxidants and free radical scavengers do not consistently delay seizure onset in animal models of acute seizures. Epilepsy \& Behavior 2008, 13:77-82

43. Turski L, Ikonomidou C, Turski WA, Bortolotto ZA, Cavalheiro EA: Cholinergic mechanisms and epileptogenesis. The seizures induced by pilocarpine: a novel experimental model of intractable epilepsy. Synapse 1989, 3:154-171.

44. Ayyildiz M, Yildirim M, Agar E: The effects of vitamin E on penicillininduced epileptiform activity in rats. Exp Brain Res 2006, 174:109-113.

45. Milatovic D, Gupta RC, Dettbarn WD: Involvement of nitric oxide in kainic acid-induced excitotoxicity in rat brain. Brain Res 2002, 957:330-337.

46. Tome AR, Feng D, Freitas RM: The effects of alpha-tocopherol on hippocampal oxidative stress prior to in pilocarpine-induced seizures. Neurochem Res 2010, 35:580-587.

47. Champney $\mathrm{TH}$, Champney JA: Novel anticonvulsant action of chronic melatonin in gerbils. Neuroreport 1992, 3:1152-1154.

48. Yamamoto HA, Mohanan PV: Ganglioside GT1B and melatonin inhibit brain mitochondrial DNA damage and seizures induced by kainic acid in mice. Brain Res 2003, 964:100-106.

49. Wu Z, Xu Q, Zhang L, Kong D, Ma R, Wang L: Protective effect of resveratrol against kainate-induced temporal lobe epilepsy in rats. Neurochem Res 2009, 34:1393-1400.

50. Shin EJ, Jeong JH, Kim AY, Koh YH, Nah SY, Kim WK, Ko KH, Kim HJ, Wie MB, Kwon YS, Yoneda Y, Kim HC: Protection against kainate neurotoxicity by ginsenosides: attenuation of convulsive behavior, mitochondrial dysfunction, and oxidative stress. J Neurosci Res 2009, 87:710-722.

51. Miyamoto R, Shimakawa S, Suzuki S, Ogihara T, Tamai H: Edaravone prevents kainic acid-induced neuronal death. Brain Res 2008, 1209:85-91.

doi:10.1186/1742-2094-8-57

Cite this article as: Hsieh et al:: Sesamin ameliorates oxidative stress and mortality in kainic acid-induced status epilepticus by inhibition of MAPK and COX-2 activation. Journal of Neuroinflammation 2011 8:57.

\section{Submit your next manuscript to BioMed Central and take full advantage of:}

- Convenient online submission

- Thorough peer review

- No space constraints or color figure charges

- Immediate publication on acceptance

- Inclusion in PubMed, CAS, Scopus and Google Scholar

- Research which is freely available for redistribution

Submit your manuscript at www.biomedcentral.com/submit
C) Biomed Central 